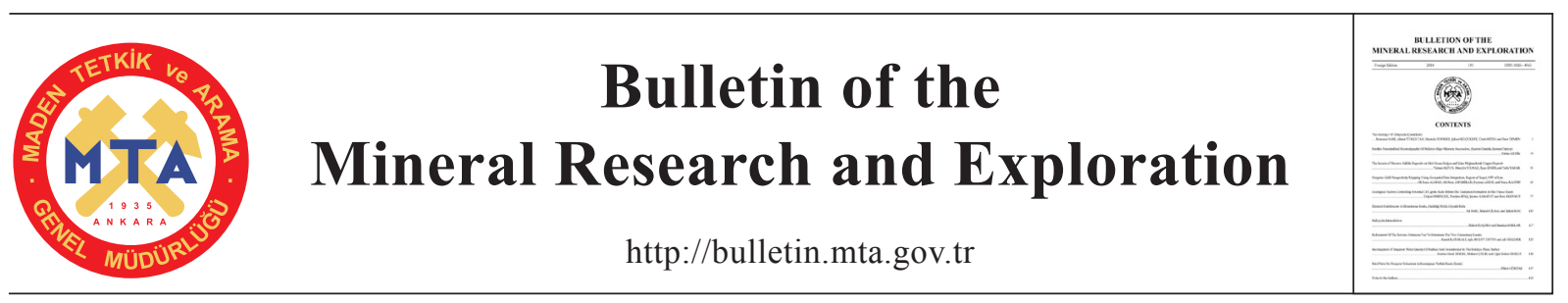

\title{
OROGENIC GOLD PROSPECTIVITY MAPPING USING GEOSPATIAL DATA INTEGRATION, REGION OF SAQEZ, NW OF IRAN
}

\author{
Alireza Almasi ${ }^{\mathrm{a} *}$, Alireza Jafarirad ${ }^{\mathrm{a}}$, Peyman Afzal ${ }^{\mathrm{b}}$ and Mana Rahimic \\ ${ }^{a}$ Department of Geology, Science and Research branch, Islamic Azad University, Tehran, 1477893855, Iran, \\ ${ }^{b}$ Department of Mining Engineering, Faculty of Engineering, Islamic Azad University, South Tehran branch, Tehran, 1777613651, Iran \\ ${ }^{c}$ Department of Geomatics, Geological Survey of Iran (GSI) Tehran, 1387835841, Iran
}

Keywords:

Mineral Prospectivity

Mapping, Index Overlay,

Fuzzy Logic, Orogenic

Gold, Sanandaj-Sirjan,

Saqez, GIS

\begin{abstract}
The aim of this study is to map orogenic gold prospecting areas in the region of Saqez, NW of Iran. In order to achieve this task geological, geochemical and airborne geophysical data are analyzed and integrated using index overlay and fuzzy logic methods. Geological map of Saqez (1:100000 scale) is used to assign lithological weights based on their favorability for hosting orogenic Au mineralization. Also a fault density map is produced and assigned based on the structural map which is included in the geological map. For preparing geochemical evidence maps, data from 535 stream sediment samples are examined using Number-Size multifractal method for $\mathrm{Au}, \mathrm{As}, \mathrm{Bi}$ and $\mathrm{Hg}$. The detected thresholds are used to assign the catchment basins of the stream sediment samples. Aeromagnetic data is employed to detect the edges of magnetic anomalies based on an enhanced edge detection method. Extracted lineaments are then converted to a density map and assigned properly. Airborne radiometric data is also used to produce two evidence maps. Potassium count grid independently and $\mathrm{K} / \mathrm{Th}$ ratio map are employed to distinguish locations with hydrothermal activity. Finally after integrating evidence maps, new locations with high potentials of Au mineralization are identified considering that the gold indications of the study area (Qolqoleh, Kervian and Ghabaghloujeh) are placed in the first priority of the fuzzy logic prospectivity map.
\end{abstract}

\section{Introduction}

The amount of digital geoscientific data available in mineral exploration is increasing rapidly, and the technologies for storing, maintaining and analyzing these data have been developing equally fast during recent years. The spatially referenced geosciences data such as airborne geophysical data, geochemical data, geological and structural data are especially suitable for quantitative analysis using a Geographic Information System (GIS), in order to derive information that is useful in mineral exploration (Jafarirad, 2009; Jafarirad and Busch, 2011; Magalhaes and Souza Filho, 2012; Nykanen et al., 2008). As stated by Luo and Dimitrakopoulos (2003), these quantitative methods are often used to: (1) extract the maximum amount of information from the data; (2) effectively combine data from diverse information sources; (3) rank potential targets (mineral sites); and (4) reduce data processing and evaluation time. In this paper, a reconnaissance scale mineral prospectivity map is presented for orogenic gold mineralization in Saqez area, northern part of Sanandaj-Sirjan metamorphic zone, NW of Iran (Figure 1).

The region under study with area of about $1800 \mathrm{~km}^{2}$ comprises Sardasht-Saqez orogenic gold zone with Qolqoleh, Kervian and Ghabaghloujeh indications in the SW (Figure 1). Former studies revealed that these gold occurrences are hosted by upper cretaceous meta-volcanosedimentary rocks and 


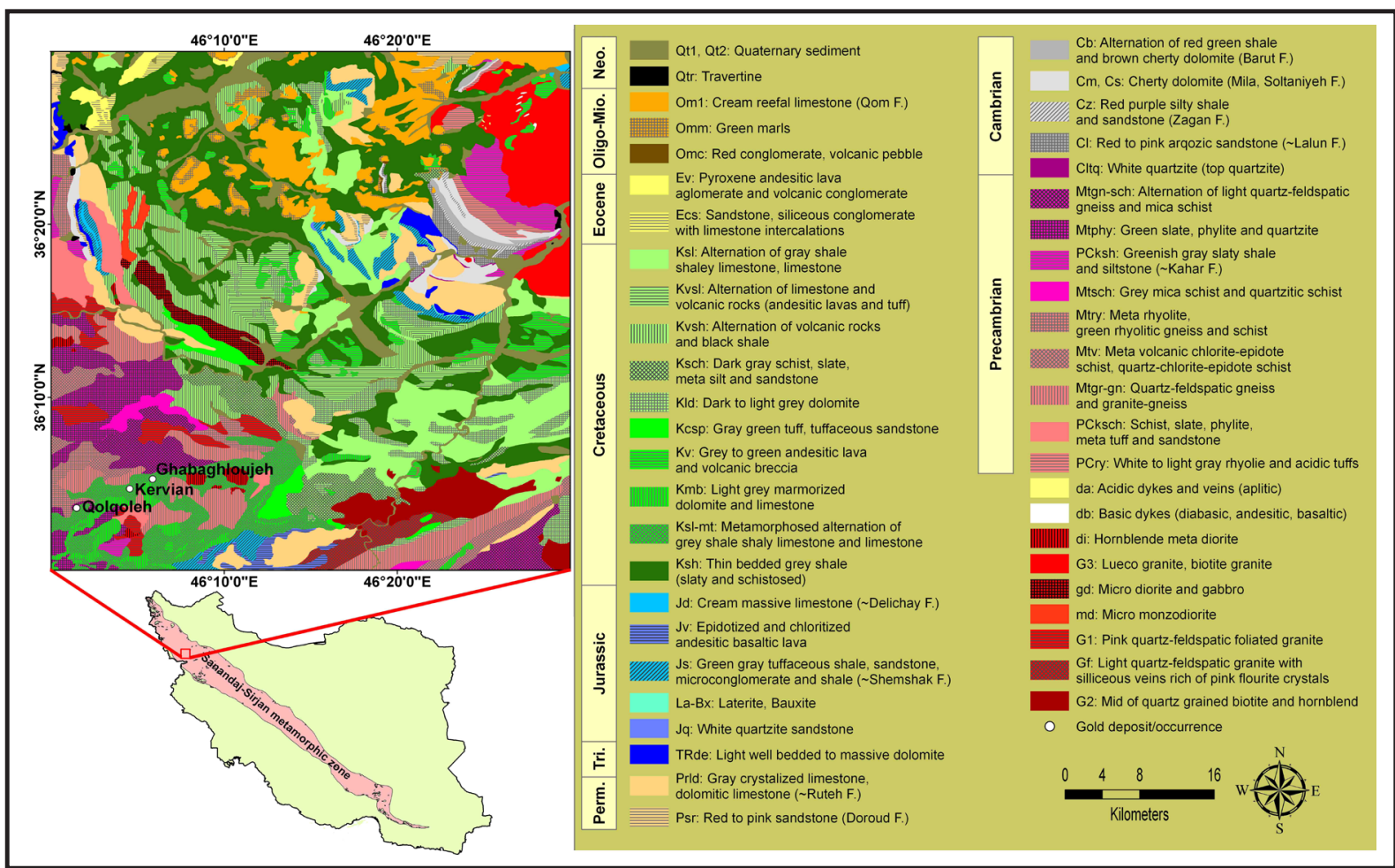

Figure 1- Saqez geological map (1:100000 scale: after Babakhani et al., 2003).

are placed over ductile to brittle shear zones and are located within or adjacent to the major deep SaqezSardasht thrust fault and other confining normal faults across this structural zone. The secondary host rock in these indications (especially in Qolqoleh) is altered mylonitic granite. Due to metamorphic genesis of $\mathrm{Au}$ mineralization in this region, felsic units are only important as heat sources for percolating hydrothermal fluids. Moreover endowment of As, $\mathrm{Bi}$ and $\mathrm{Hg}$ have been recorded in these indications (Aliyari et al., 2007, 2009, 2012; Tajeddin, 2011).
Information about the genesis model and effective factors in $\mathrm{Au}$ mineralization derived from the former studies was summarized in table 1 , and was used to comprehend the genetic model for gold prospectivity mapping. Due to few known Au deposits/indications in the study area, knowledge-driven index overlay and fuzzy logic approaches were chosen for preparing information layers and integration (Bonham Carter, 1994; Carranza, 2008; Magalhaes and Souza Filho, 2012; Nykanen et al., 2008).

Table 1- Characteristics of Qolqoleh, Kervian and Ghabaghloujeh deposits/indications.

\begin{tabular}{|c|c|c|c|c|c|c|}
\hline $\begin{array}{l}\text { Deposit/ } \\
\text { indication }\end{array}$ & Host rocks & Genetic type & $\begin{array}{c}\text { Age of } \\
\text { mineralization }\end{array}$ & $\begin{array}{l}\text { Enriched element(s) } \\
\text { / structural features }\end{array}$ & $\begin{array}{l}\text { Resource }(t) \\
\text { grade }(g / t)\end{array}$ & Data source \\
\hline Qolqoleh & $\begin{array}{l}\text { Meta-sedimentary, } \\
\text { mafic to interamediate } \\
\text { (andesite to andesitic } \\
\text { basalt) meta-volcanic } \\
\text { rocks, sericite schist }\end{array}$ & $\begin{array}{l}\text { Orogenic } \\
\text { (ductile to } \\
\text { brittle } \\
\text { shear zone) }\end{array}$ & $\begin{array}{l}\text { Upper } \\
\text { Cretaceous- } \\
\text { Tertiary }\end{array}$ & $\begin{array}{c}\text { As and } \mathrm{Hg} / \\
\text { intersecting faults and } \\
\text { fractures }\end{array}$ & $\begin{array}{c}\text { Up to } \\
0.37 \mathrm{Moz} \\
@ \\
3.5 \mathrm{~g} / \mathrm{t}\end{array}$ & $\begin{array}{l}\text { Aliyari et al., } \\
\text { (2007, 2009); } \\
\text { Tajeddin, } \\
(2011)\end{array}$ \\
\hline Kervian & $\begin{array}{l}\text { Meta-sedimentary and } \\
\text { felsic to mafic meta- } \\
\text { volcanic rocks }\end{array}$ & $\begin{array}{l}\text { Orogenic } \\
\text { (ductile } \\
\text { shear zone) }\end{array}$ & $\begin{array}{l}\text { Upper } \\
\text { Cretaceous- } \\
\text { Tertiary }\end{array}$ & $\begin{array}{c}\mathrm{As}, \mathrm{Bi} \text { and } \mathrm{Hg} / \\
\text { intersecting faults and } \\
\text { fractures }\end{array}$ & Unknown & $\begin{array}{l}\text { Heidari, } \\
\text { (2004); } \\
\text { Heidari et al., } \\
\text { (2006); } \\
\text { Tajeddin, } \\
\text { (2011) }\end{array}$ \\
\hline Qabaqloujeh & $\begin{array}{l}\text { Phyllite, schist meta- } \\
\text { volcanic, } \\
\text { and mylonitic rocks }\end{array}$ & $\begin{array}{l}\text { Orogenic } \\
\text { (ductile to } \\
\text { brittle shear } \\
\text { zone) }\end{array}$ & $\begin{array}{l}\text { Upper } \\
\text { Cretaceous- } \\
\text { Tertiary }\end{array}$ & $\begin{array}{c}\text { As and } \mathrm{Bi} / \\
\text { intersecting faults and } \\
\text { fractures }\end{array}$ & $\begin{array}{c}0.035(\mathrm{Moz}) \\
@ \\
1 \mathrm{~g} / \mathrm{t}\end{array}$ & $\begin{array}{l}\text { Tajeddin, } \\
\text { (2011) }\end{array}$ \\
\hline
\end{tabular}




\section{Materials}

Saqez region because of its high potential for diverse kinds of mineralization was the subject of different surveys in recent years. Hence, geochemical data used in this research comes from 535 stream sediment samples which were gathered and analyzed by Geological Survey of Iran (GSI) in 2005. The samples were chemically analyzed using fire assay method for Au and ICP-MS method for Au pathfinders As, Bi and $\mathrm{Hg}$. Detection limit for analyzing $\mathrm{Au}$ was $1 \mathrm{ppb}$ and detection limits for analyzing As, $\mathrm{Bi}$ and $\mathrm{Hg}$ were $0.5,0.1$ and 0.1 ppm respectively. In order to produce geochemical anomaly maps and considering the fact that stream sediment samples represent upstream lithologies, elemental concentrations were assigned to the catchment basins of the samples.

Meanwhile, aeromagnetic and aeroradiometric data are from two separate airborne geophysical surveys. In northern part of the study area with area of about $1546 \mathrm{Km}^{2}$, aeromagnetic and aeroradiometric data were achieved from a helicopter-borne geophysical survey that was carried out by Prakla and Austirex for Atomic Energy Organization of Iran (AEOI) in 1976. Line spacing and flight elevation of this survey were 500 and 120 meters respectively. In the south-western part (polygonal shape zone) with area of about $283 \mathrm{~km}^{2}$, aeromagnetic and aeroradiometric data are from a geophysical survey which was conducted by Fugro Airborne Surveys Corporation and GSI in 2006 with line spacing and flight elevation of 200 and 60 meters respectively.

In order to include all the information layers in final integrations the study area was limited to the extension of the airborne geophysical surveys (the rectangular shape in the north and the polygonal shape in the southwest). Microsoft office excel 7 and Oasis Montaj (6.4.1 CN) software were used for analyzing geochemical and airborne geophysical data respectively, and ArcGIS 9.3 was employed for producing and integrating evidence maps.

\section{Preparing information layers}

In order to produce raster information layers (evidence or factor maps) with assigned crisp numbers between 1-10, or fuzzy memberships (0-1) using fuzzy functions such as linear, large and near (Bonham Carter, 1994; Carranza, 2008; Nykanen et al., 2008; Tsoukalas \& Uhrig, 1997), geological, geochemical, aeromagnetic and airborne radiometric data had to be analyzed and interpreted using a range of different methods. In order to prevent missing data in the places where one information layer among overlapping layers does not have a value (nodata), crisp value 1 or a $\sim 0$ fuzzy value were assigned to such areas. Coordinate system for all the maps is UTM (Universal Transfer Mercator) zone 38N. The steps of preparing each layer are presented in following sections.

\subsection{Geochemical data}

Number-Size (N-S) multifractal model (Mandelbrot, 1983; Deng et al., 2010; Hashemi and Afzal, 2013) was applied on the geochemical data from stream sediment samples in order to delineate anomaly thresholds for $\mathrm{Au}, \mathrm{As}, \mathrm{Bi}$ and $\mathrm{Hg}$. Thereafter for producing geochemical anomaly maps, the detected thresholds were used to classify the catchment basins of the samples (Figure 2). Afterwards for preparing factor maps, crisp values 1-10 were assigned to each geochemical map based on the thresholds resulted from N-S multifractal analysis (Table 2). Meanwhile fuzzy memberships for $\mathrm{Au}, \mathrm{As}, \mathrm{Bi}$ and $\mathrm{Hg}$ were produced using fuzzy large function with midpoint and spread of 7 and 5 for $\mathrm{Au}$ and 7 and 3 for elemental paragenesis respectively (Table 2).

\subsection{Airborne geophysical data}

Airborne geophysical data including aeromagnetic and aeroradiometric data resulted in producing three separate evidence maps. Aeromagnetic data is known as an important source of information for studying lineaments and structures (Bierlein et al., 2006; Henson et al., 2010; Li, 2013). Many edge detection filters such as analytic signal, vertical derivative, total horizontal derivative (THD) and tilt derivative (TDR) are available to accomplish this task (Ferreira et al., 2011; Verduzco et al., 2004). However in this research, after removing IGRF from northern and southern Total Magnetic Intensity (TMI) maps, in order to place the magnetic anomalies over their causative bodies and to minimize the effects of shallow magnetic sources, Reduction to The Pole (RTP) and Upward Continuation (UC) filters were applied on TMIs respectively. Thereafter for detecting the magnetic edges THD and TDR were applied on RTP UCs respectively (Almasi et al., 2014). For rasterizing the edges and converting them into an evidence map, a density map which calculates the density of linear features in the neighborhood of each output grid cell (Silverman, 1986) was produced and 


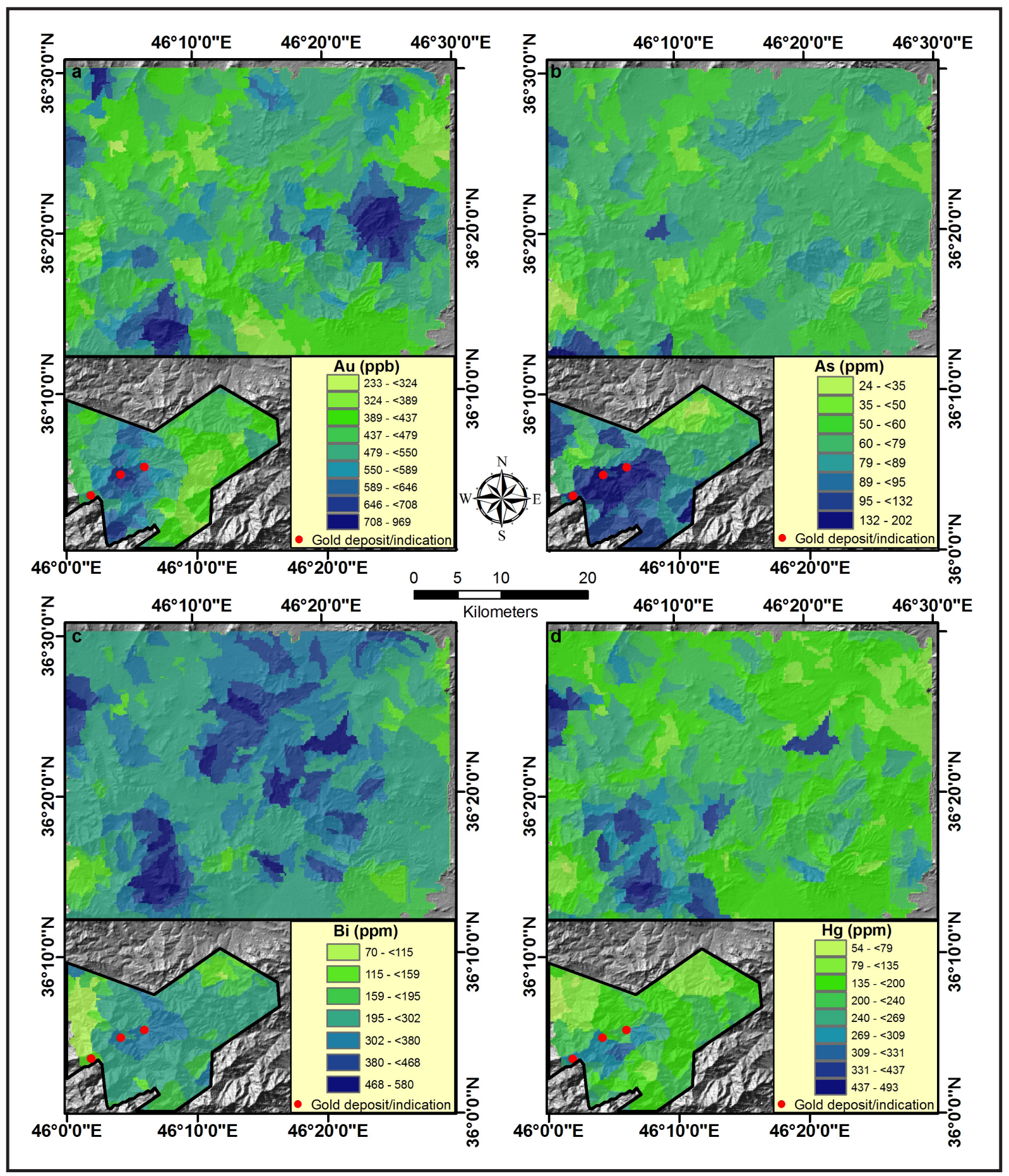

Figure 2- Geochemical maps for a) Au, b) As, c) Bi and d) Hg using N-S multifractal model.

assigned 1-10 (Figure 3). Fuzzy membership of the lineaments' density map was produced using fuzzy large function with midpoint and spread of 7 and 5 respectively (Figure 3).

Airborne radiometric data is capable of mapping felsic igneous rocks which contain high amounts of radioactive elements (Th, $\mathrm{K}$ and $\mathrm{U}$ ), and also is able for mapping places with hydrothermal activities (de Souza Filho et al., 2007; Magalhães and Souza Filho 2012; Silva et al. 2003). Potassium count data and the ratio of $\mathrm{K} / \mathrm{Th}$ (after Airo, 2001, 2007) are used to distinguish these locations. $\mathrm{K} / \mathrm{Th}$ ratio anomalies for north and south of the study area were mapped and assigned appropriately. Converting $\mathrm{K}$ count into an information layer was based on the 
Table 2- Crisp (C) and fuzzy (F) values based on N-S thresholds for Au, As, Bi and $\mathrm{Hg}$

\begin{tabular}{|c|c|c|c|c|c|c|c|c|c|c|c|}
\hline \multirow{2}{*}{$\begin{array}{c}\text { Au thresholds } \\
\text { (ppb) }\end{array}$} & \multicolumn{2}{|c|}{ Value } & \multirow{2}{*}{$\begin{array}{c}\text { As thresholds } \\
\quad(p p m)\end{array}$} & \multicolumn{2}{|c|}{ Value } & \multirow{2}{*}{$\begin{array}{c}\text { Bi thresholds } \\
\text { (ppm) }\end{array}$} & \multicolumn{2}{|c|}{ Value } & \multirow{2}{*}{$\begin{array}{c}\text { Hg thresholds } \\
\text { (ppm) }\end{array}$} & \multicolumn{2}{|c|}{ Value } \\
\hline & $\mathrm{C}$ & $\mathbf{F}$ & & C & $\mathbf{F}$ & & $\mathrm{C}$ & $\mathbf{F}$ & & $\mathrm{C}$ & $\mathbf{F}$ \\
\hline Nodata & 1 & $\sim 0$ & Nodata & 1 & 0.003 & Nodata & 1 & 0.003 & Nodata & 1 & 0.003 \\
\hline $233-<324$ & 2 & 0.002 & $24-<35$ & 3 & 0.07 & $70-<115$ & 4 & 0.16 & $54-<79$ & 2 & 0.02 \\
\hline $324-<389$ & 3 & 0.014 & $35-<50$ & 4 & 0.16 & $115-<159$ & 5 & 0.27 & $79-<135$ & 3 & 0.07 \\
\hline $389-<437$ & 4 & 0.06 & $50-<60$ & 5 & 0.27 & $159-<195$ & 6 & 0.39 & $135-<200$ & 4 & 0.16 \\
\hline $437-<479$ & 5 & 0.16 & $60-<79$ & 6 & 0.39 & $195-<302$ & 7 & 0.5 & $200-<240$ & 5 & 0.27 \\
\hline $479-<550$ & 6 & 0.32 & $79-<89$ & 7 & 0.5 & $302-<380$ & 8 & 0.6 & $240-<269$ & 6 & 0.39 \\
\hline $550-<589$ & 7 & 0.5 & $89-<95$ & 8 & 0.6 & $380-<468$ & 9 & 0.68 & $269-<309$ & 7 & 0.5 \\
\hline $589-<646$ & 8 & 0.66 & $95-<132$ & 9 & 0.68 & $468-580$ & 10 & 0.74 & $309-<331$ & 8 & 0.6 \\
\hline $646-<708$ & 9 & 0.78 & $132-202$ & 10 & 0.74 & & & & $331-<437$ & 9 & 0.68 \\
\hline $708-969$ & 10 & 0.86 & & & & & & & $437-<493$ & 10 & 0.74 \\
\hline
\end{tabular}

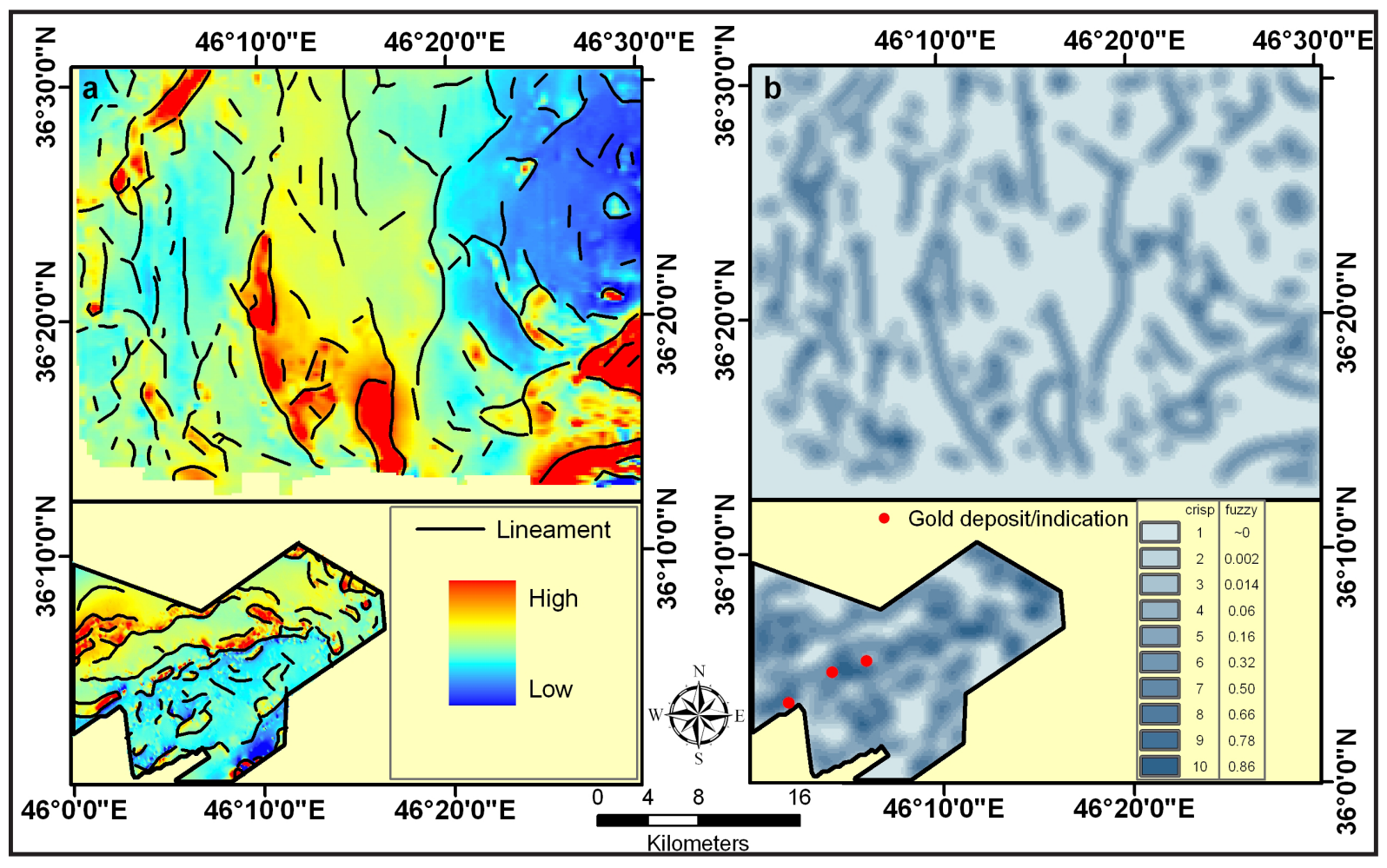

Figure 3- a) extracted lineaments using enhanced edge detection method with RTP in the background, b) lineaments' density map and its assigned crisp and fuzzy values.

correlation of high amounts of potassium count with felsic intrusions and its median value over hydrothermal activities and the edges of felsic units (after Airo, 2001, 2007) where the gold indications and Au anomalies of the study area are placed. Thus for enhancing median amount in potassium count grids, near function with midpoint and spread of 5 and 0.003 respectively was applied on the $\mathrm{K}$ grid, thereafter this layer was assigned 1-10.
Near fuzzy function is used for enhancing an intermediate crisp value in a fuzzy set. The spread and mid parameters are subjectively defined to reflect the expert opinion. An example of the near algorithm is given in figure 4 . The near function is also known as a sinusoidal membership function (Burrough and McDonnell, 1998; Tsoukalas and Uhrig, 1997). 


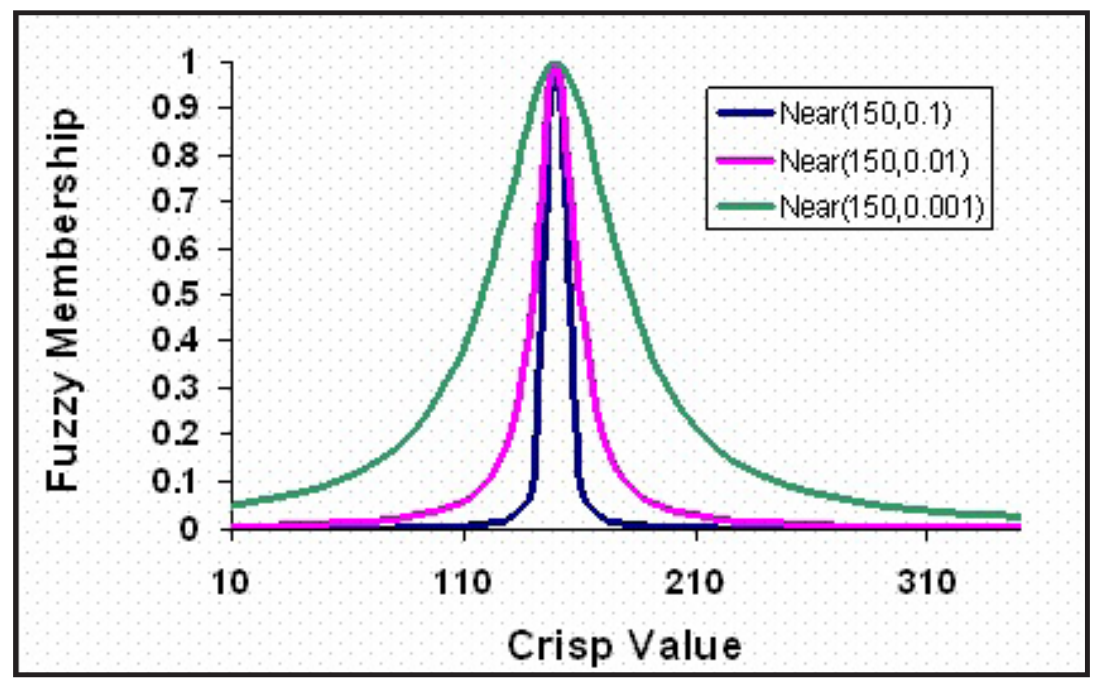

Figure 4- Example of near fuzzification using different midpoint and spread values.

Fuzzy membership of $\mathrm{K}$ layer was generated by applying fuzzy large function with midpoint and spread of 7 and 5 respectively on the median enhanced $\mathrm{K}$ map (Figure 5).

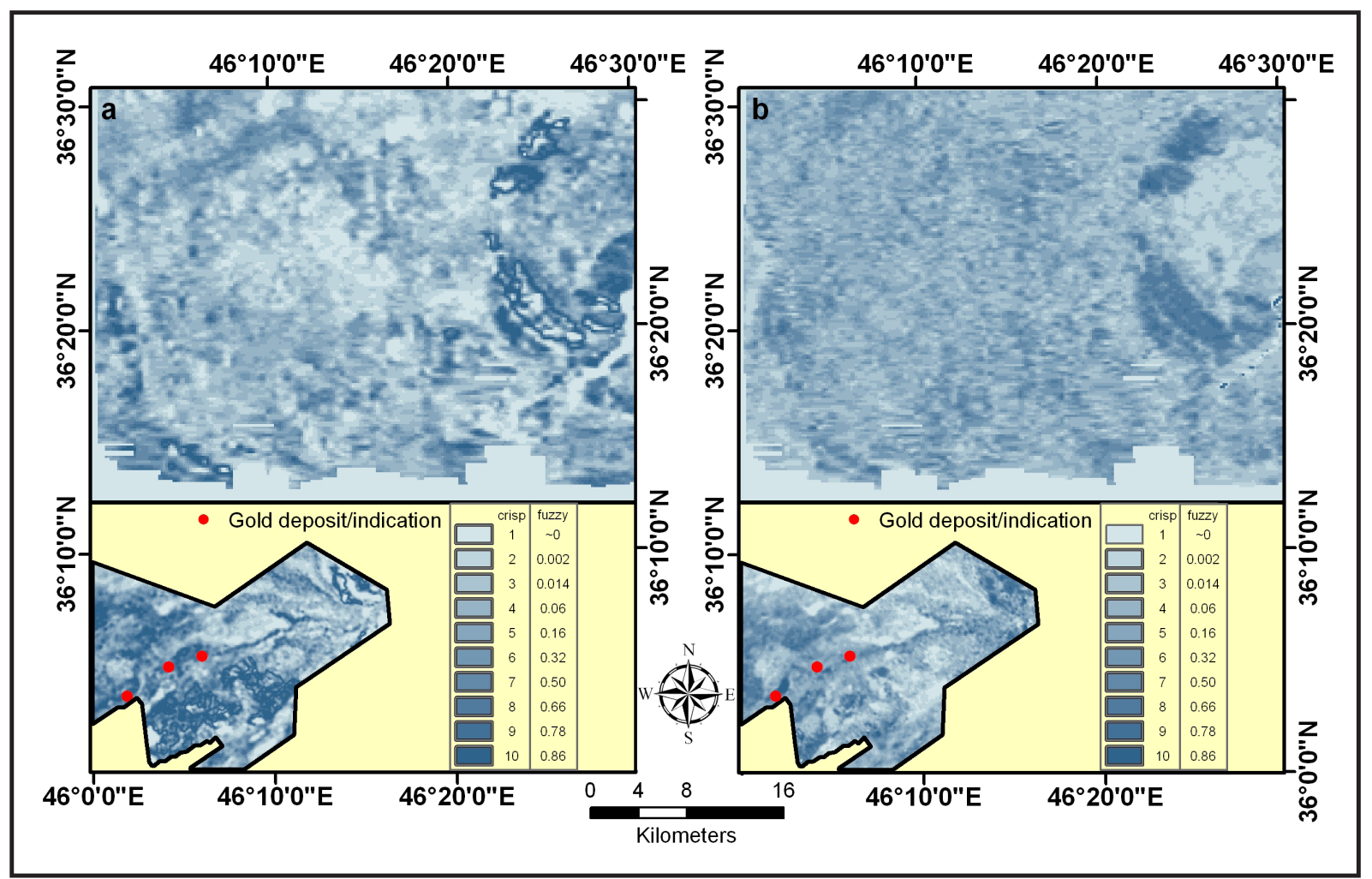

Figure 5-a) K evidence map and fuzzy membership, b) K/Th evidence map and fuzzy membership.

\subsection{Geological data}

For weighing the geological map, host rocks of the gold indications (Qolqoleh, Kervian and Ghabaghloujeh) were considered as highest values and lithological units were assigned based on their favorability for $\mathrm{Au}$ mineralization (Table 1). For instance geological units Ksl-mt and Mtgr-gn which represent meta-volcanosedimentary and mylonitic granites of the geological map (Figure 1) were assigned with the weights 10 and 9 respectively. Other units were weighed based on their similarity to 
the host lithologies and their properness for hosting $\mathrm{Au}$ mineralization. For example units Mtgn-sch, Ksh, Mtgn-sch and Ksh were given weights of 8 and 7 were other meta-volcanosedimentary units of the study area. In order to produce geological evidence map, the rest of the lithologies were assigned using the values presented in table 3 (Figure 6). In addition, fuzzy membership of the geological units was produced with multiplying $8 / 100$ by the crisp values of the table 3 .

Table 3-Crisp and fuzzy values assigned to the lithological units of the geological map

\begin{tabular}{|c|c|c|}
\hline Units & Crisp & Fuzzy \\
\hline Ksl-mt & 10 & 0.8 \\
\hline Mtgr-gn & 9 & 0.72 \\
\hline Mtgn-sch, Ksh & 8 & 0.64 \\
\hline PCry, Ksl & 7 & 0.56 \\
\hline Gd, Kcsp, & 6 & 0.48 \\
\hline G1,Kvsh, PCksh & 5 & 0.4 \\
\hline di, G3, Kmb, Mtphy, & 4 & 0.32 \\
\hline $\mathrm{Cb}, \mathrm{Cl}, \mathrm{Cs}, \mathrm{Cz}, \mathrm{Js}$, Mtry, Mtsch, Mtv, Om1, PCksch, Prld, Psr, Qtr, TRde & 3 & 0.24 \\
\hline Other units or Nodata & 1 & 0.08 \\
\hline
\end{tabular}

Another information layer was also produced using fault lines of the Saqez geological map (1:100000 scale: Babakhani et al., 2003). These structures were used for building a density map and then assigned
1-10. Its fuzzy membership was constructed using fuzzy large function with midpoint and spread of 7 and 5 respectively (Figure 6).

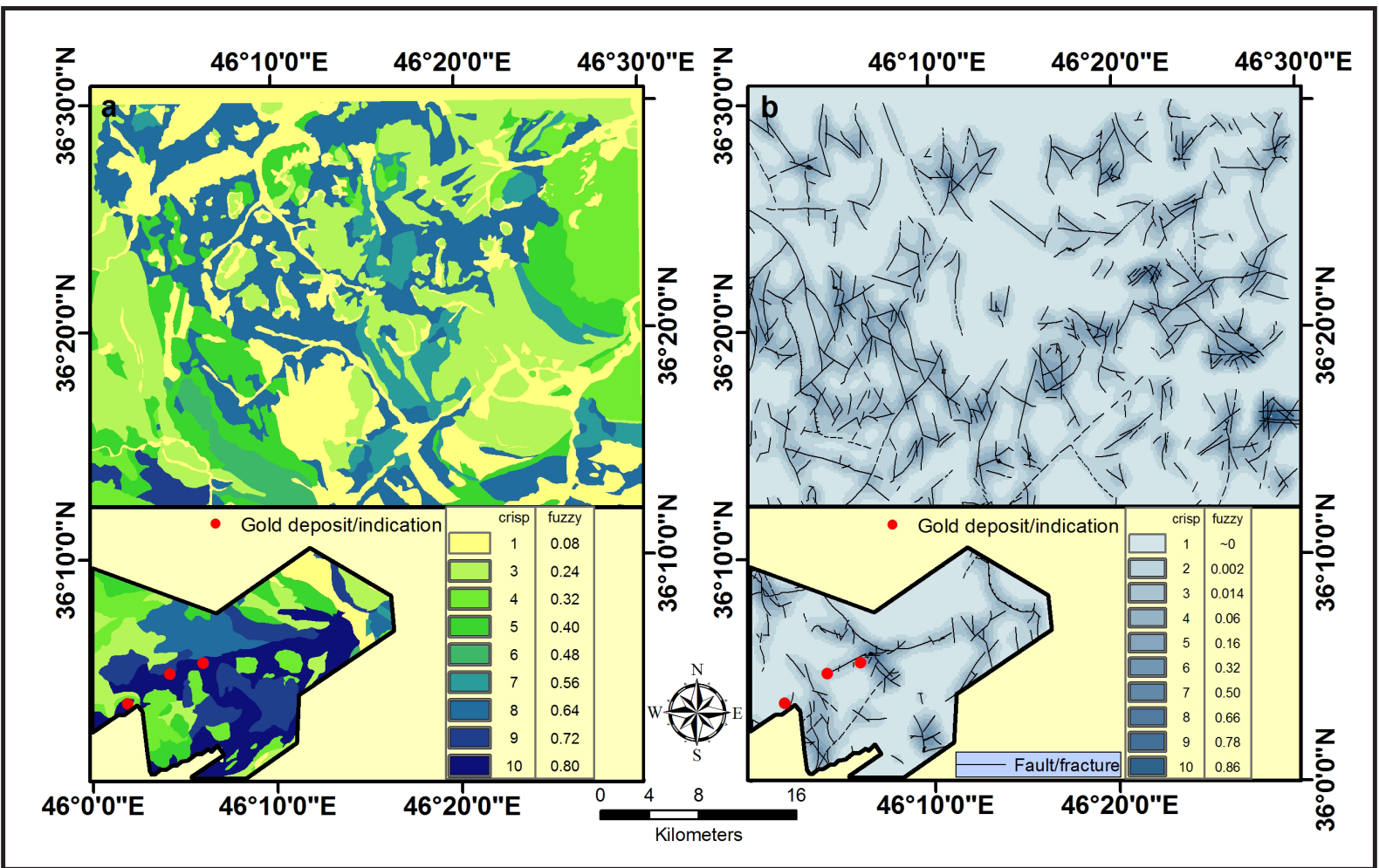

Figure 6- a) geological unit information layer and its fuzzy membership, b) structures (faults and fractures) of the geological map and its assigned crisp and fuzzy values using density map. 


\section{Index overlay and fuzzy logic methods}

Mineral prospectivity maps were generated with integrating factor maps using knowledge-driven index overlay and fuzzy logic methods (Bonham Carter, 1994, Nykanen et al., 2008). Index overlay integration is based on following equation:

$$
\mathrm{S}=\sum \mathrm{W}_{\mathrm{i}} \mathrm{S}_{\mathrm{ij}} / \sum \mathrm{W}_{\mathrm{i}} \quad \text { (equation 1) }
$$

Where:

$\mathrm{Wi}=$ the weight of ith factor map (which is 1 in simple overlay)

$\mathrm{Sij}=$ the ith spatial class weight of $\mathrm{jth}$ factor map

$\mathrm{S}=$ the spatial unit value in output map

Different weights were multiplied in each layer based on their relativity and correlation with orogenic gold type mineralization of the study area. Some examples of multi-class index overlay modeling applied to mineral prospectivity mapping can be found in Harris et al. (2001), Chico-Olmo et al. (2002) and Billa et al. (2004).

The fuzzy set theory which was established by Zadeh (1965) is the cornerstone of fuzzy logic modeling. Demicco and Klir (2004) discuss the rationale and illustrate the applications of fuzzy logic modeling to geological studies but they do not provide examples of fuzzy logic applications to mineral prospectivity mapping. Recent examples of applications of fuzzy logic modeling to mineral prospectivity mapping are found in Carranza and Hale (2001), Carranza (2002), Tangestani and Moore (2003), Ranjbar and Honarmand (2004), Rogge et al. (2006) and Nykänen et al. (2008). Typically, application of fuzzy logic modeling to knowledgedriven mineral prospectivity mapping involves three main feed-forward stages: (1) fuzzification of evidential data; (2) logical integration of fuzzy evidential maps with the aid of an inference network and appropriate fuzzy set operations; and (3) defuzzification of fuzzy mineral prospectivity output in order to aid its interpretation. Each of these stages in fuzzy logic modeling of mineral prospectivity is employed in this study in order to orogenic gold prospectivity mapping in the case study area.

\section{Results and discussion}

The biggest challenge in orogenic gold prospectivity mapping in GIS was defining a unified and clear exploration model based on the genesis of the gold occurrences in the study area. Presences of different overlapping signs of mineralization were needed for converting a place to a high potential prospect. The other challenge was having only three known Au occurrences in the study area (Qolqoleh, Kervian and Ghabaghloujeh gold occurrences) which was a limitation for using an empirical (data-driven) integration method such as weight of evidence. On the other hand, the strength was having a variety of datasets especially high resolution airborne geophysical data. Nine evidence maps namely $\mathrm{Au}, \mathrm{As}, \mathrm{Bi}, \mathrm{Hg}$ (Figure 2 and table 2), aeromagnetic lineaments (Figure 3b), $\mathrm{K}$ (Figure 5a), K/Th (figue 5b), lithologies (Figure 6a) and faults of the geological map (Figure 6b) were generated and assigned with crisp values. In this stage each on these layers were given a value based on their importance for orogenic gold exploration in the study area. Weight 10 was selected for geological structures, lineaments extracted from aeromagnetic data and $\mathrm{Au}$ factor maps, 9 was considered for $\mathrm{K}$ map, 8 was chosen for $\mathrm{K} / \mathrm{Th}$ and geology factor maps and 7 was multiplied in the layers of As, Bi and $\mathrm{Hg}$. After integration with index overlay, values 7 and 8 were considered as the first priority for orogenic $\mathrm{Au}$ mineralization in the prospectivity maps and values 6 and 5 were selected as second and third priorities respectively (Figure 7a and b). Area of the first, second and third priorities are $9.33,68.82$ and $271.48 \mathrm{~km}^{2}$.

$\mathrm{Au}, \mathrm{As}, \mathrm{Bi}, \mathrm{Hg}$ (Figure 2 and table 2), aeromagnetic lineaments (Figure 3b), K (Figure 5a), $\mathrm{K} / \mathrm{Th}$ (Figure 5b), lithologies (Figure 6a) and faults of the geological map (Figure $6 \mathrm{~b}$ ) fuzzy memberships were produced using fuzzification techniques. For fuzzy modeling, fuzzy or operator was employed in order to combine similar fuzzy members: 1) elemental paragenesis As, Bi and $\mathrm{Hg}, 2$ ) structures (Figure $6 \mathrm{~b}$ ) and lineaments (Figure $3 \mathrm{~b}$ ) and 3 ) $\mathrm{K}$ and $\mathrm{K} / \mathrm{Th}$ ratio (Figure 5). Secondly, these layers were integrated with other fuzzy memberships which were produced in former stages such as geology and $\mathrm{Au}$ layers using gamma operator with gamma value of 0.8 . Finally for defuzzification and prioritizing fuzzy logic mineral prospectivity map, Concentration-Area (C-A) multifractal model (after Cheng et al., 1994; Afzal et al., 2012) was applied on the pixel values of the generated map (Figure 8). Values greater than 0.6 were considered as the first priority, values 0.46 to 0.6 was considered as second priority and values 0.28 to 0.46 was regarded as the third priority (Figure 9). Area of the first, second and third priorities are 11.82, 52.13 and $227.62 \mathrm{~km}^{2}$. 


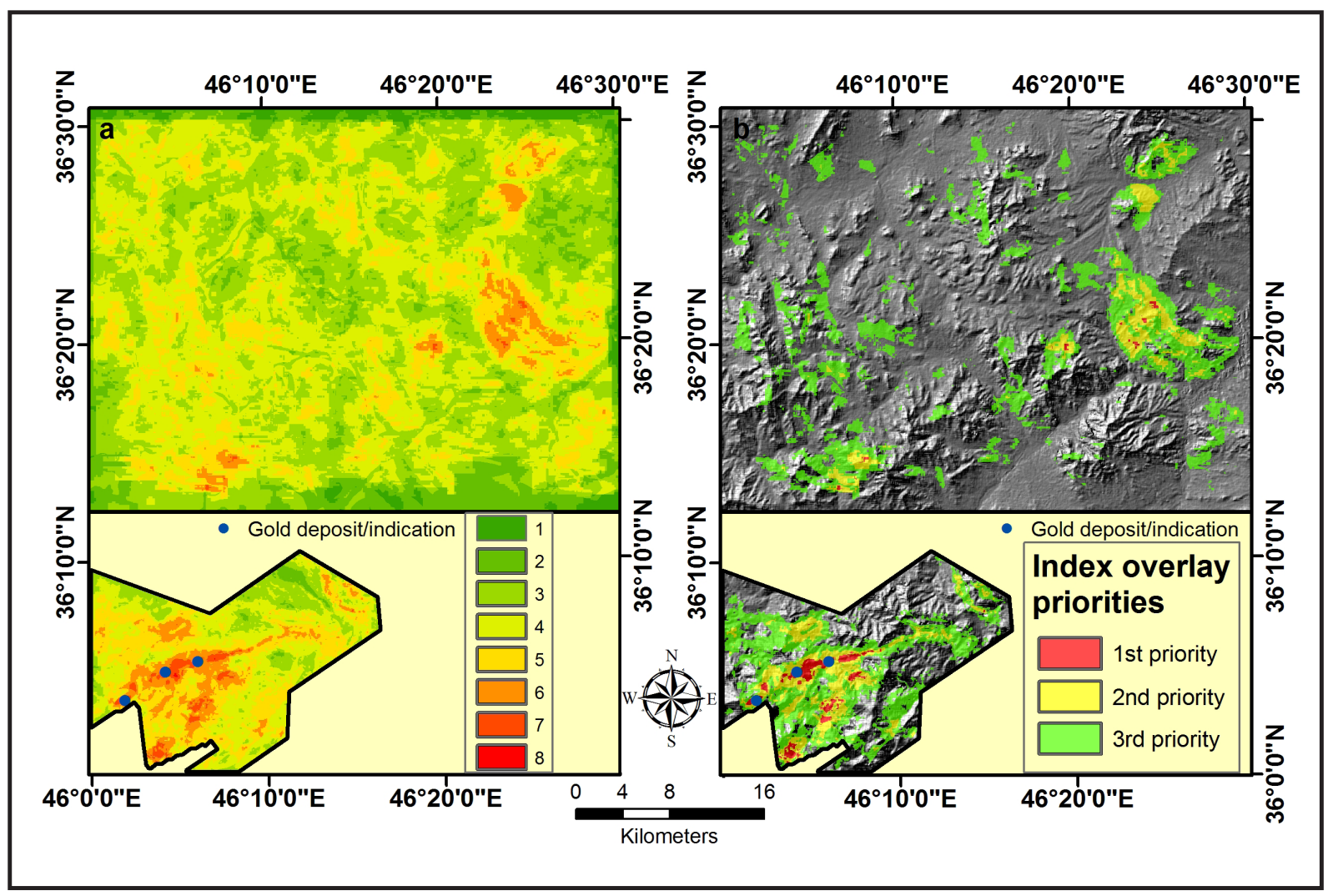

Figure 7- a) orogenic gold prospectivity map using index overlay, b) indicated priorities.

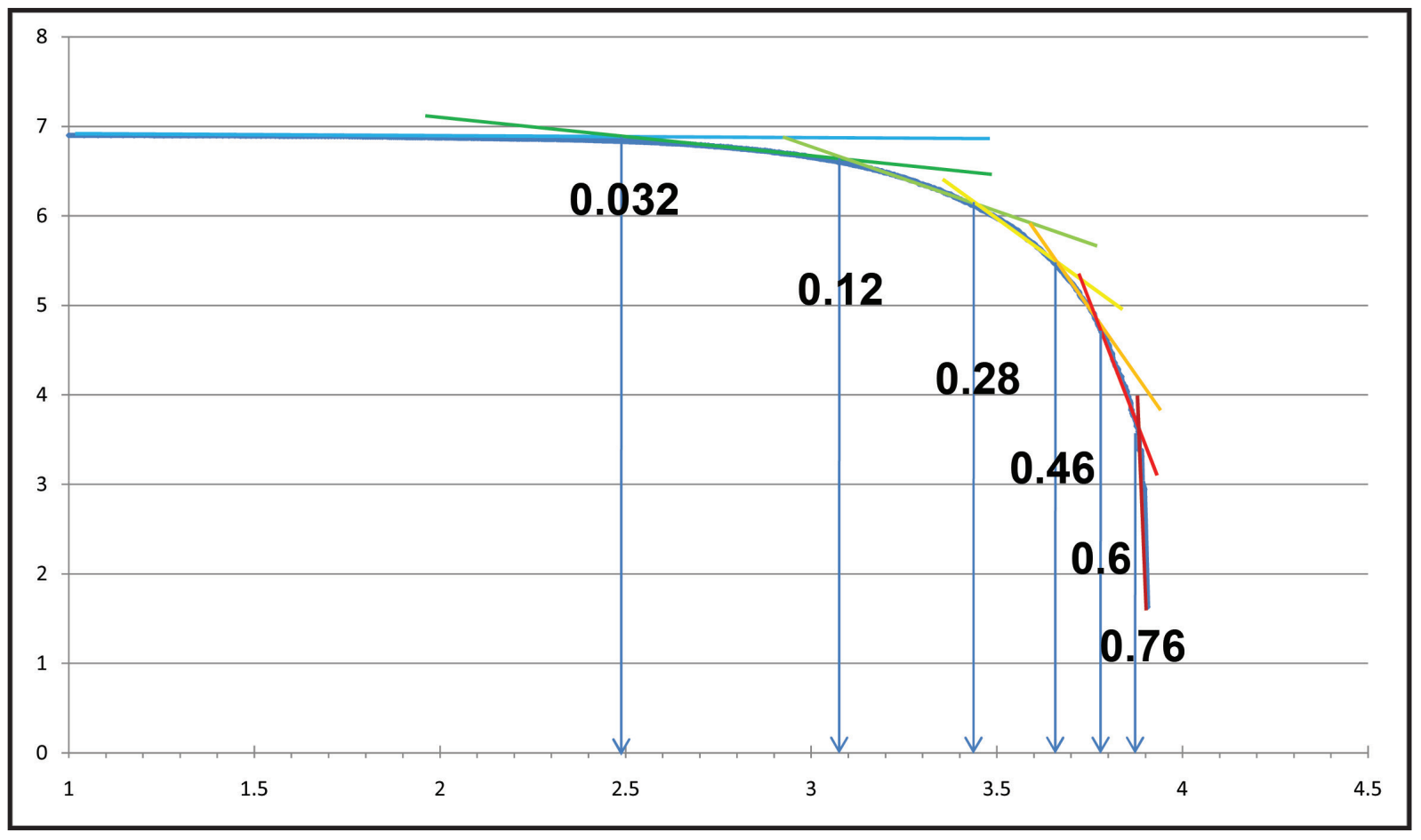

Figure 8- C-A log-log plot and the delineated thresholds for prioritizing fuzzy logic integration. 


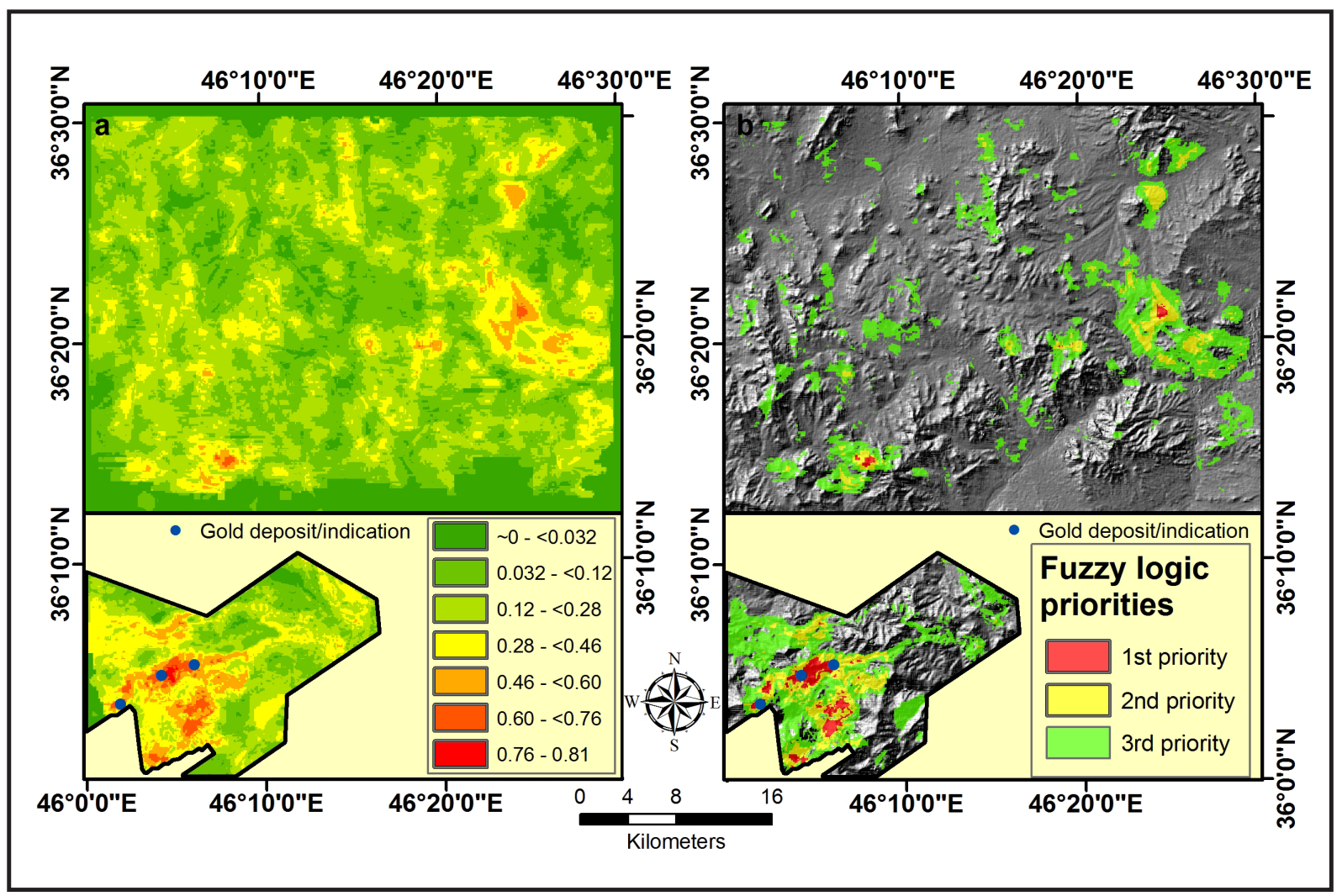

Figure 9- a) orogenic gold prospectivity map using fuzzy logic, b) indicated priorities.

\section{Conclusion}

Data integration using GIS resulted in the following main conclusions:

1) Comparing the areas of the first priorities in fuzzy logic and index overlay modeling (fuzzy: $11.82 \mathrm{~km}^{2}>$ index overlay: $9.33 \mathrm{~km}^{2}$ ) revealed that fuzzy logic model is more powerful for orogenic gold prospectivity mapping and it is less likely for fuzzy modeling to lose a high potential location.

2) In the mineral prospectivity map resulted from index overlay integration model (Figure 7), Qolqoleh and Kervian gold occurrences are located in the first priority but Ghabaghloujeh occurrence is placed in the second priority area, however in the prioritized orogenic gold prospectivity map of the fuzzy logic model (figure 9) all the three gold indications are located in the first priority zone, which is another score for fuzzy modeling.

3) Concentration-Area (C-A) multifractal model is an effective technique for defuzzification of the mineral prospectivity map resulted from fuzzy logic modeling.
4) Other first priority locations have been specified in the south and north of the Sardasht-Saqez zone and also in the east of the study area (Figure 9). These locations are suggested for more exploration and field checking.

5) Most important evidences for orogenic gold prospectivity mapping are faults and fractures and hydrothermal activity which can be exposed using airborne magnetic and radiometric data.

6) $\mathrm{Au}$ anomalies in the NW of the study area (Figure 2) and their absence in final potential maps can be construed as a sign for having other types of Au mineralization in the region.

\section{Acknowledgement}

Authors would like to acknowledge the guidance of Dr. Hassan Kheyrollahi in interpreting airborne geophysical data.

Received: 04.05.2014 Accepted: 28.08.2014 Published: June 2015 


\section{References}

Afzal P., Zarifi A. Z., Khankandi S. F., Wetherelt A., Yasrebi A. B. 2012. Separation of uranium anomalies based on geophysical airborne analysis by using Concentration-Area (C-A) Fractal Model, Mahneshan 1:50000 Sheet, NW IRAN. Journal of Mining and Metallurgy 48 A (1), 1-11.

Airo M. L. 2001. Aeromagnetic and aeroradiometric response to hydrothermal alteration. Surveys in Geophysics 23, 273-302.

Airo M. L. 2007. Application of aerogeophysical data for gold exploration: implications for the central lapland greenstone belt. Geological Survey of Finland, Special Paper 44, 187-208.

Aliyari F., Rastad E., Zengqian H. 2007. Orogenic Gold Mineralization in the Qolqoleh Deposit, Northwestern Iran. Resource Geology 57(3), 269282.

Aliyari F., Rastad E., Arehart G. B. 2009. Geology and geochemistry of D-O-C isotope systematics of the Qolqoleh Gold Deposit, Northwestern Iran; implications for ore genesis. Ore Geology Reviews 36, 306-314.

Aliyari F., Rastad E., Mohajjel M. 2012. Gold Deposits in the Sanandaj-Sirjan Zone: Orogenic Gold Deposits or Intrusion-Related Gold systems? Resource Geology 62(3), 296-315.

Almasi A., Jafarirad A., Kheyrollahi H., Rahimi M., Afzal P., 2014. Evaluation of structural and geological factors in orogenic gold type mineralisation in the Kervian area, north-west Iran, using airborne geophysical data. Exploration Geophysics, http:// dx.doi.org/10.1071/EG13053.

Babakhani A. R., Hariri A., Farjandi F. 2003. Geological map of Saqez (1:100000 scale). Geological Survey of Iran (GSI).

Bierlein F. P., Murphy F. C., Weinberg R. F., Lees T. 2006. Distribution of orogenic gold deposits in relation to fault zones and gravity gradients: targeting tools applied to the Eastern Goldfields, Yilgarn Craton, Western Australia. Mineralium Deposita 41, 107126.

Billa M., Cassard D., Lips A.L.W., Bouchot V., Tourliére B., Stein G., Guillou-Frottier L. 2004. Predicting gold-rich epithermal and porphyry systems in the central Andes with a continental-scale metallogenic GIS. Ore Geology Reviews 25(1-2), 39-67.

Bonham Carter G. F. 1994. Geographic Information Systems for Geoscientists - Modelling with GIS (Computer Methods in the Geosciences 13). Pergamon Press, New York.

Burrough P.A.,McDonnell R.A. 1998. Principles of geographical information systems. New York, Oxford University Press, 333 pp.

Carranza E.J.M. 2002. Geologically-constrained mineral potential mapping (examples from the Philippines),
Ph.D. Thesis, Delft University of Technology, The Netherlands, ITC (International Institute for Geo-Information Science and Earth Observation) Publication No. 86, Enschede, 480 pp.

Carranza E. J. M. 2008. Geochemical anomaly and mineral prospectivity mapping in GIS. Handbook of Exploration and Environmental Geochemistry, Vol. 11. Elsevier, Amsterdam.

Carranza E. J. M., Hale M. 2001. Geologically-constrained fuzzy mapping of gold mineralization potential, Baguio district, Philippines. Natural Resources Research 10(2), 125-136.

Cheng Q. M., Agterberg F. P., Ballantyne S. B. 1994. The separation of geochemical anomalies from background by fractal methods. Journal of Geochemical Exploration 51, 109-130.

Chica-Olmo M., Abarca F., Rigol J.P. 2002. Development of a decision support system based on remote sensing and GIS techniques for gold-rich area identification in SE Spain. International Journal of Remote Sensing 23(22), 4801-4814.

De Souza Filho C. R., Nunes A. R., Leite E. P., Monteiro L. V. S., Xavier R. B. 2007. Spatial analysis of airborne geophysical data applied to geological mapping and mineral prospecting in the Serra Leste region, Caraja's Mineral Province, Brazil. Surveys in Geophysics 28, 377-405.

Demicco R., Klir G. (Eds.) 2004. Fuzzy Logic in Geology, Elsevier, Amsterdam.

Deng J., Wang Q., Yang L., Wang Y., Gong Q., Liu H. 2010. Delineation and explanation of geochemical anomalies using fractal models in the Heqing area, Yunnan Province, China. Journal of Geochemical Exploration 105, 95-105.

Ferreira F., de Castro L., Bongiolo A., de Souza J., Romeiro M. 2011. Enhancement of the total horizontal gradient of magnetic anomalies using tilt derivatives: Part II - Application to real data. SEG Technical Program Expanded Abstracts 2011, 887-891.

Harris J.R., Wilkinson L., Heather K., Fumerton S., Bernier M.A., Ayer J., Dahn R. 2001. Application of GIS processing techniques for producing mineral prospectivity maps - a case study: mesothermal $\mathrm{Au}$ in the Swayze Greenstone Belt, Ontario, Canada. Natural Resources Research 10(2), 91-124.

Hashemi M., Afzal P. 2013. Identification of geochemical anomalies by using of number-size $(\mathrm{N}-\mathrm{S})$ fractal model in Bardaskan area, NE Iran. Journal of Arabian Geosciences 6, 4785-4794.

Henson P. A., Blewett R. S., Roy I. G., Miller J. McL., Czarnota K. 2010. 4D architecture and tectonic evolution of the Laverton region, eastern Yilgarn Craton, Western Australia. Precambrian Research $183,338-355$.

Heidari S. M. 2004. Mineralogy, geochemistry and fabrics of gold mineralization in the Kervian ductile shear 
zone (southwest of Saqez). University of Tarbiat Modares, Tehran, Iran, M.Sc. thesis, 245 pp.

Heidari S. M., Rastad E., Mohajjel M., Shamsa M. J. 2006. Gold mineralization in ductile shear zone of Kervian (southwest of Saqez). Geosciences 58, 18-37.

Jafarirad A. R. 2009. Modeling of conceptual and Empirical Geospatial Datasets for Mineral Prospecting Mapping. TUC, Germany, PhD dissertation, 190 pp.

Jafarirad A. R., Busch W. 2011. Porphyry copper mineral prospectivity mapping using interval valued fuzzy sets topsis method in central Iran. Journal of Geographic Information System 3, 312-317.

$\mathrm{Li}$ L. 2013. Improved edge detection tools in the interpretation of potential field data. Exploration Geophysics 44, 128-132.

Luo X., Dimitrakopoulos R. 2003. Data-driven fuzzy analysis in quantitative mineral resource assessment. Computers and Geosciences 29, 3-13.

Magalhães L. A., Souza Filho C. R. 2012. Targeting of Gold Deposits in Amazonian Exploration Frontiers using Knowledge- and Data-Driven Spatial Modeling of Geophysical, Geochemical, and Geological Data. Survey in Geophysics 33, 211-241.

Mandelbrot B. B. 1983. The Fractal Geometry of Nature. Freeman, San Francisco.

Nykänen V., Groves D. I., Ojala V. J., Eilu P., Gardoll S. J. 2008. Reconnaissance-scale conceptual fuzzylogic prospectivity modelling for iron oxide copper - gold deposits in the northern Fennoscandian Shield, Finland. Australian Journal of Earth Sciences 55(1), 25-38.

Ranjbar H., Honarmand M. 2004. Integration and analysis of airborne geophysical and ETM+ data for exploration of porphyry type deposits in the Central
Iranian Volcanic Belt using fuzzy classification. International Journal of Remote Sensing 25(21), 4729-4741.

Rogge D.M., Halden N.M., Beaumont-Smith C. 2006. Application of data integration for shearhosted $\mathrm{Au}$ potential modelling: Lynn Lake Greenstone Belt, Northwestern Manitoba, Canada. In: J.R. Harris (Ed.), GIS for the Earth Sciences, Geological Association of Canada Special Publication 44, Geological Association of Canada, St. John's, pp. 191-210.

Silva A. M., Pires A. C. B., Mccafferty A., Moraes R. A. V., Xia H. 2003. Application of airborne geophysical data to mineral exploration in the uneven exposed terrains of the Rio Das Velhas greenstone belt. Revista Brasileira de Geociencias 33, 17-28.

Silverman B. W. 1986. Density Estimation for Statistics and Data Analysis. Chapman and Hall, New York, $177 \mathrm{pp}$.

Tangestani M.H., Moore F. 2003. Mapping porphyry copper potential with a fuzzy model, northern Shahr-e-Babak, Iran. Australian Journal of Earth Sciences 50(3), 311-317.

Tajeddin H. 2011. Gold ore controlling factors in metamorphic rocks of Saqez-Sardasht, NW of Sananda-Sirjan metamorphic zone. Tarbiat Modarres University, Tehran, Iran, PhD dissertation, $436 \mathrm{pp}$.

Tsoukala L. H., Uhrig R. E. 1997. Fuzzy and Neural Approaches in Engineering. Wiley, New York.

Verduzco B., Fairhead J. D., Green C. M., MacKenzie C. 2004. New insights into magnetic derivatives for structural mapping. The Leading Edge 23(2), 116119.

Zadeh L.A. 1965. Fuzzy sets. IEEE Information and Control 8(3), 338-353. 